\title{
Introduction of Graphene Oxide as Buffer Layer in Perovskite Solar Cells and the Promotion of Soluble n-Butyl-substituted Copper Phthalocyanine as Efficient Hole Transporting Material
}

Esmaiel Nouri $^{a+}$, Yu-Long Wang ${ }^{b}$, Qian Chen $^{b}$, Jia-Ju Xu $^{b}$, Georgios Paterakis ${ }^{a, c}$, Vassilios Dracopoulos $^{c}$, Zong-Xiang X $u^{b^{*}}$, Dimitrios Tasis ${ }^{d}$, Mohammad Reza Mohammadi ${ }^{e}$, Panagiotis $\operatorname{Lianos}^{a} *$

${ }^{\mathrm{a} D e p a r t m e n t ~ o f ~ C h e m i c a l ~ E n g i n e e r i n g, ~ U n i v e r s i t y ~ o f ~ P a t r a s, ~} 26500$ Patras, Greece

${ }^{\mathrm{b}}$ Department of Chemistry, South University of Science and Technology of China, ShenZhen, GuangDong, P. R. China, 518055

${ }^{\mathrm{c} F O R T H / I C E-H T, ~ P . O . ~ B o x ~ 1414, ~} 26504$ Patras, Greece

${ }^{\mathrm{d}}$ Department of Chemistry, University of Ioannina, 45110 Ioannina, Greece

${ }^{\mathrm{e}}$ Department of Materials Science and Engineering, Sharif University of Technology, Azadi Str., Tehran, Iran

${ }^{+}$Permanent Address: Department of Materials Science and Engineering, Sharif University of Technology, Azadi Str., Tehran, Iran

*Corresponding authors: lianos@upatras.gr (P.Lianos), xu.zx@sustc.edu.cn (Z.-X.Xu)

Key words: copper phthalocyanine; perovskite solar cells; graphene oxide; buffer layer 


\begin{abstract}
Organometal halide perovskite solar cells have been constructed using soluble tetra-nbutyl-copper phthalocyanine as hole transporting material. Devices were constructed and characterized under ambient conditions of 50-60\% ambient humidity. Soluble copper phthalocyanine gave a modest PCE of $7.3 \%$ but when a buffer layer of either $\mathrm{Al}_{2} \mathrm{O}_{3}$ or graphene oxide was introduced between the perovskite and the hole transporting layer the cell efficiency extensively increased and reached $14.4 \%$ in the presence of graphene oxide. Corresponding data obtained by employing the standard spiro-OMeTAD as hole transporter gave equivalent performance. Combination then of tetra-n-butyl-copper phthalocyanine with graphene oxide offers a very good alternative of simpler and stable materials for perovskite solar cell construction. The presently recorded data highlight the role of the buffer layer, especially graphene oxide, as the material which blocks shunt paths and facilitates hole transfer between the perovskite and the hole transporting layer.
\end{abstract}




\section{Introduction}

Organic-inorganic mesoscopic solar cells have followed a remarkable route that marked a very popular research field in materials science. It started with dye-sensitized solar cells, about 25 years ago [1] and instead of getting "old" it has led to a new and very promising domain with the introduction of organometal halide perovskites, following the seminal work of Miyasaka et al. [2]. Perovskite solar cells (PSCs) are solid state hybrid organic-inorganic devices where the standard structure follows a n-i-p scheme, i.e. a nanostructured n-type semiconductor, typically nanoparticulate titania (np- $\left.\mathrm{TiO}_{2}\right)$, an intrinsic semiconductor, i.e. the perovskite, and an organic p-type semiconductor, i.e. the hole transporter. The n-i-p layers are usually deposited on a transparent electrode, for example, an FTO glass as electron collecting anode and they are completed by depositing a metal counter electrode on the top, typically, a thin layer of Au. The strong interest in PSCs is supported by the ease of device construction, the high charge carrier mobility in organometal halide perovskites $[3,4]$ and the ensuing high photon-to-charge conversion efficiency (PCE), which currently overpasses $20 \%$ [5,6]. Even though, the efficiency of PSCs is now competing with the best of inorganic photovoltaics, there are still a lot to be learned about these interesting systems [7]. One of the main components of PSCs, which has raised some skepticism, is the standard hole transporting material (HTM), namely spiro-OMeTAD $\left(2,2^{\prime}, 7,7^{\prime}-\right.$ Tetrakis-(N,Ndi-4-methoxyphenylamino)-9,9'-spirobifluorene). This material is expensive to synthesize or to acquire, it has a limited conductivity which necessitates the utilization of additives [8] and its stability is questioned $[\mathbf{9 , 1 0 ]}$. Attempts to substitute spiro-OMeTAD by other HTM gave exploitable results [11-13], even though, no one has overpassed its records. A p-type material that has attracted particular interest is $\mathrm{Cu}$ and $\mathrm{Zn}$ phthalocyanine [14-19], which do not compete spiro-OMeTAD records either but they have other advantages. These molecules are very stable. Thus they may be deposited non-destructively by thermal evaporation. They have 
the tendency to aggregate but this comes out to be an advantage, since they form crystalline phases offering high conductivity values necessary for their application as HTM. We are recently studying copper phthalocyanine $(\mathrm{CuPc})$ molecules and we have gone through a successful process of material (and device) amelioration by developing alkyl substituted soluble CuPc. Thus it has been found that n-butyl-substitution of CuPc has not impeded but rather facilitated $\mathrm{CuPc}$ molecular packing and $\pi-\pi$ interaction leading to progressive increase of PSC device efficiency $[\mathbf{1 7}, \mathbf{1 8}]$.

A very important factor, which improves PSC performance, is the deposition of a buffer layer between the perovskite and the hole transporting layer. $\mathrm{Al}_{2} \mathrm{O}_{3}$ is a standard choice for this purpose [20]. Moreover, $\mathrm{SiO}_{2}$ [21], montmorillonite [22], $\mathrm{ZrO}_{2}$ [23], $\mathrm{ZnO}$ [24], glycerol-doped PEDOT:PSS [25], LiF and $\mathrm{C}_{60}$ [26] are further examples of buffer layer for solid-state solar cells. The buffer layer plays a multiple role in solar cell functionality. The simplest and most effective one is that its presence discourages the formation of shunt paths towards both electrodes, which may result in a decrease of shunt resistance and thus a drop in Fill Factor (FF) and open-circuit voltage $V_{O C}$ of the cell $[\mathbf{2 0 - 2 4 , 2 7 ]}$. The buffer layer also prevents any corrosive additives employed with spiro-OMeTAD to reach and destroy the perovskite layer [22]. Furthermore, it provides a porous framework, which organizes the formation of the upper HTM layer, facilitating proper film formation even in a case of a hardly soluble and hardly processable HTM [20,28]. By improving the formation of the HTM layer, it facilitates hole transfer and conduction and limits charge recombination [20-22,25]. It can also improve the stability of the PSCs [26]. Having these data in mind, in the present work we have successfully tried to improve CuPc performance as HTM in the presence of a buffer layer, using soluble n-butyl-substituted $\mathrm{CuPc}(\mathrm{CuBuPc})$ as functional component. We have tested standard $\mathrm{Al}_{2} \mathrm{O}_{3}$ but we have also studied graphene oxide $(\mathrm{GO})$ for the same purpose. $\mathrm{GO}$ has been used as a buffer layer less frequently than $\mathrm{Al}_{2} \mathrm{O}_{3}$ [29-31]. We have 
chosen GO because of its high band gap, its transparency and its mesoporous structure. GO has demonstrated itself as a very good choice for this purpose. It must be underlined at this point that carbon nanostructures in PSCs have been reported to improve stability of the cells [32]. This favorable behavior is probably due to their hydrophobicity and water-repelling capacity, as it has been observed in other cases [33-35]. Corresponding data have been recorded by also employing spiro-OMeTAD, as a reference HTM component.

\section{Experimental}

\section{Materials}

All materials were purchased from Aldrich, unless otherwise specified, and they were used as received. Commercial nanocrystalline titania Degussa P25 was used in all cell constructions and Millipore water was used in all experiments. $\mathrm{SnO}_{2}: \mathrm{F}$ transparent conductive electrodes (FTO, Resistance $8 \Omega /$ square) were purchased from Pilkington.

\section{Synthesis of n-butyl substituted CuPc (CuBuPc)}

A mixture of 4-butylphthalonitrile (1.0 g, $5.4 \mathrm{mmol})$, copper(II) chloride (0.24 g, 1.8 mmol), 1,8-diazabicyclo[5.4.0]undec-7-ene $(0.2 \mathrm{~mL})$, and 1-pentanol $(2 \mathrm{~mL})$ were stirred at reflux under argon for $2 \mathrm{~h}$. The reaction mixture was cool to room temperature and petroleum ether $(50 \mathrm{~mL})$ was added to precipitate the product. The suspension was stirred for $5 \mathrm{~min}$, filtered and the residue washed with $\mathrm{CH}_{2} \mathrm{Cl}_{2}(30 \mathrm{~mL})$. The filtrates were combined and the solvent was removed by rotary evaporation. The crude product was purified by column chromatography with $\mathrm{CH}_{2} \mathrm{Cl}_{2} /$ ethanol $(\mathrm{v} / \mathrm{v}, 1 / 3)$ as the eluent to give a blue product. The product was further purified by repeated recrystallization from $\mathrm{CH}_{2} \mathrm{Cl}_{2}$ /ethanol to give $\mathrm{CuBuPc}(0.38 \mathrm{~g}, 35 \%)$. To fulfill the requirements of electronic applications, the product was further purified by vacuum sublimation in a sublimation machine (Technol VDS-80) operated 
at $400{ }^{\circ} \mathrm{C}$ and $\sim 3 \times 10^{-3} \mathrm{~Pa}$. Elemental analysis calcd (\%) for $\mathrm{C}_{48} \mathrm{H}_{48} \mathrm{CuN}_{8}: \mathrm{C}, 72.02 ; \mathrm{H}, 6.04$; N, 14.00; found: C, 71.89; H, 6.10; N, 13.89. ESI-MS: m/z (M+) 799.33. UV-Vis $\left(\mathrm{CHCl}_{3}\right)$ : $\lambda_{\max }=678 \mathrm{~nm}\left(195625 \mathrm{~L} \cdot \mathrm{mol}^{-1} \cdot \mathrm{cm}^{-1}\right), 611 \mathrm{~nm}\left(43360 \mathrm{~L} \cdot \mathrm{mol}^{-1} \cdot \mathrm{cm}^{-1}\right) . \mathrm{IR}\left(\mathrm{K}_{\mathrm{Br}}\right): v=2950$, 2924, 2855, 1611, 1504, 1456, 1405, 1337, 1159, 1095, 1064, 819, 737, $720 \mathrm{~cm}^{-1}$.

\section{Preparation of Graphene Oxide (GO) dispersion}

GO was synthesized from pre-oxidized graphite flakes by the Hummers and Offeman method [36]. Briefly, in the first step, $5 \mathrm{~g}$ of graphite flakes (99.95\%), $3 \mathrm{~g}$ of $\mathrm{K}_{2} \mathrm{~S}_{2} \mathrm{O}_{8}$ and $3 \mathrm{~g}$ of $\mathrm{P}_{2} \mathrm{O}_{5}$ were dissolved in $20 \mathrm{~mL}$ concentrated $\mathrm{H}_{2} \mathrm{SO}_{4}(95 \mathrm{wt} . \%)$ and stirred at $80^{\circ} \mathrm{C}$ for about $8 \mathrm{~h}$. The resultant mixture was then diluted with $1 \mathrm{~L}$ deionized water and filtered using a porous membrane (0.45 micron). Washing procedure was carried out until achieving neutral $\mathrm{pH}$. The pre-oxidized graphite flakes were obtained by drying the final product at $40^{\circ} \mathrm{C}$ overnight. In a second step, the above oxidized graphite powder was added into $100 \mathrm{~mL}$ concentrated $\mathrm{H}_{2} \mathrm{SO}_{4}(95 \mathrm{wt} . \%)$ in an ice bath $\left(0{ }^{\circ} \mathrm{C}\right)$ and were stirred until dissolution. $12 \mathrm{~g}$ of $\mathrm{KMnO}_{4}$ and $4 \mathrm{~g}$ of $\mathrm{NaNO}_{3}$ were then added gradually and successively into the mixture, controlling its temperature around $20^{\circ} \mathrm{C}$. The cooling bath was then removed and the solution was transferred to a $35{ }^{\circ} \mathrm{C}$ water bath for gas releasing under continuous stirring for about $1 \mathrm{~h}$ to obtain a thick green paste. Afterwards, $180 \mathrm{~mL}$ of deionized water was slowly added into the paste, causing violent effervescence and an increase of temperature up to $98{ }^{\circ} \mathrm{C}$. The temperature of the diluted dark brown mixture was kept constant at $98{ }^{\circ} \mathrm{C}$ for 20 min with vigorous stirring in order to increase the oxidation degree of the GO product. Then $300 \mathrm{ml}$ of warm deionized water was added to further dilute the mixture, which was treated with $30 \mathrm{~mL}$ of $30 \% \mathrm{H}_{2} \mathrm{O}_{2}$, drop by drop within $10 \mathrm{~min}$, in order to reduce the residual permanganate and manganese dioxide to colorless soluble manganese sulfate. The color of the final solution turned to yellow-pale brown. To eliminate the residual metal ions, the filtered cake was 
washed and filtered four times with warm deionized water and a $10 \% \mathrm{HCl}$ solution in ethanol and water until the $\mathrm{pH}$ reached a neutral level (ca. 6.4). The product was further diluted to approximately $400 \mathrm{~mL}$ with deionized water and ultrasonicated at boost mode for $40 \mathrm{~min}$. The yellow-brown GO dispersion was then subjected to dialysis to completely remove metal ions and acids. Finally, it was dehydrated in an air oven at $40{ }^{\circ} \mathrm{C}$ for $14 \mathrm{~h}$ to yield the $\mathrm{GO}$ powder. $10 \mathrm{mg}$ of the GO powder was added in $2 \mathrm{~mL}$ isopropanol alcohol, then placed in an ultrasonic water bath for $1 \mathrm{~h}$ to ensure good exfoliation.

\section{Preparation of $\mathrm{Al}_{2} \mathrm{O}_{3}$ dispersion}

A colloidal dispersion of aluminum oxide $\left(\mathrm{Al}_{2} \mathrm{O}_{3}\right)$ nanoparticles $[<50 \mathrm{~nm}$ particle size (DLS), 20 wt. \% in isopropanol] has been used. It was further diluted by sonicating $200 \mu \mathrm{L}$ of this colloidal dispersion in $2 \mathrm{~mL}$ isopropanol.

\section{Solar cell device construction}

FTO-coated glass substrates were cut in pieces of dimensions $1 \mathrm{~cm} \times 3 \mathrm{~cm}$. One third of the conductive layer was removed using zinc powder and hydrochloric acid. Then they were washed with mild detergent, rinsed several times with distilled water and subsequently with ethanol and acetone in an ultrasonic bath, finally dried under air stream. A compact thin layer of $\mathrm{TiO}_{2}$ was then deposited on this patterned and cleaned FTO electrode by aerosol spray pyrolysis using a solution of $0.2 \mathrm{M}$ Diisopropoxytitanium bis(acetylacetonate) in EtOH. After spraying, the samples were heated for 1 hour at $500^{\circ} \mathrm{C}$. Subsequently, a mesoporous $\mathrm{TiO}_{2}$ layer composed of titania paste made of $\mathrm{P} 25$ nanoparticles was spin coated at $4000 \mathrm{rpm}$ for 60 seconds and then dried at $100{ }^{\circ} \mathrm{C}$ for $20 \mathrm{~min}$ and calcined for 30 minutes at $500{ }^{\circ} \mathrm{C}$. After that the samples were treated in $\mathrm{TiCl}_{4}$ by dipping into a solution made of $0.04 \mathrm{M} \mathrm{TiCl}{ }_{4}$ in $\mathrm{H}_{2} \mathrm{O}$ for 30 minutes at $70{ }^{\circ} \mathrm{C}$, then copiously rinsing and finally calcining at $500^{\circ} \mathrm{C}$. Active 
perovskite layer was deposited on the thus prepared titania film by the following procedure. A precursor solution was made by mixing $253 \mathrm{mg} \mathrm{PbCl}_{2}$ and $507 \mathrm{mg} \mathrm{PbI}_{2}$ with $270 \mathrm{mg}$ methyl ammonium iodide in a mixture of $1 \mathrm{ml} \mathrm{N}-\mathrm{N}$-dimethylformamide (DMF) and $0.5 \mathrm{ml}$ dimethylsulfoxide (DMSO). The solution was kept under stirring for about 2 hours at about $80{ }^{\circ} \mathrm{C}$ and then deposited by two consecutive spin-coating steps; first $1000 \mathrm{rpm}$ for $10 \mathrm{~s}$, then $6000 \mathrm{rpm}$ for $30 \mathrm{~s}$. During the second step, $1 \mathrm{~mL}$ chlorobenzene, as an anti-solvent, was gently dropped on the spinning substrate. The layer was then heated at $90{ }^{\circ} \mathrm{C}$ for about 45 min, which made the sample's color turn from yellow to black. Thereafter, thin mesoporous buffer layers were spin-coated directly on the annealed perovskite layer at room temperature. Both $\mathrm{Al}_{2} \mathrm{O}_{3}$ and $\mathrm{GO}$ layers were deposited at $2000 \mathrm{rpm}$ for $60 \mathrm{~s}$. The hole transporting material (HTM) was then deposited by spin coating at $3000 \mathrm{rpm}$ for $60 \mathrm{~s}$. The HTM solutions were prepared by dissolving $36 \mathrm{mg}$ of HTM powders (spiro-OMeTAD or CuBuPc) in $1 \mathrm{ml}$ of chlorobenzene. In these solutions we added $28.8 \mu \mathrm{L}$ of 4-tert-butylpyridine (TBP) and 17.5 $\mu \mathrm{L}$ of a stock solution of Lithium bis (trifluoromethane sulfonyl) imide (Li-TFSI) in acetonitrile $(520 \mathrm{mg} / 1 \mathrm{~mL})$. All of these procedures were carried out under ambient conditions of $50-60 \%$ relative humidity. The last step for preparing the solid state solar cell was the deposition of $90 \mathrm{~nm}$ thick gold electrodes by thermal evaporation under vacuum. The thickness of the subsequent layers forming the solar cells can be seen in the FESEM cross-

sectional images of Figure 1. These unit devices had an active size of $15 \mathrm{~mm}^{2}(10 \mathrm{~mm} \times 1.5$ $\mathrm{mm})$ as defined by the size of the gold electrodes.

\section{Characterizations}

Illumination of the solar cells was made with a PECCELL PEC-L01 Solar Simulator set at $100 \mathrm{~mW} / \mathrm{cm}^{2}$, through a mask of aperture size $1 \times 6 \mathrm{~mm}^{2} . \mathrm{J}-\mathrm{V}$ characteristic curves were recorded under ambient conditions with a Keithley 2601 source meter that was controlled by 
Keithley computer software (LabTracer). IPCE values were obtained with an Oriel IQE 200 system. X-ray diffraction (XRD) patterns were obtained with a D8 Advance Bruker diffractometer with $\mathrm{Cu} \mathrm{K \alpha}$ radiation $(\lambda=1.5406 \AA)$. Absorption and photoluminescence spectra using thin transparent perovskite films were recorded with a Cary 1E UV-Vis spectrophotometer and a Cary Eclipse Fluorescence spectrometer, respectively. FESEM/EDX measurements were made using a Zeiss SUPRA 35VP with a field emission gun equipped with an EDX system (QUANTA 200, Bruker AXS). Electrochemical Impedance Spectroscopy (EIS) characterization has been carried out on PSC devices with a potentiostat/galvanostat (PGSTAT128N, Autolab B.V., Netherlands) under both dark and AM-1.5G illuminated conditions.

\section{Results and discussion}

\section{Construction of PSCs and materials characterization}

As detailed in the experimental section, PSCs were constructed by successive layer deposition of the functional components. This is pictorially summarized in Figure 1 showing a cross-sectional FESEM image of a device. Furthermore, Figure 2 shows the FESEM top views of the subsequent layers. Thus Figure 2a shows the top view of the mesoporous titania film composed of commercial Degussa P25 nanoparticles. The perovskite film formed within the mesoporous titania structure and on its top is imaged in Figures $\mathbf{2 b}$ and $\mathbf{c}$ showing that it attained a fully-covered compact structure without voids. Figure $\mathbf{2 d}$ shows GO flakes on the top of the perovskite film and, finally, Figures $2 \mathbf{e}$ and $\mathbf{f}$ depict the top view of the CuBuPc film, without (e) and with an underlying GO layer (f). CuBuPc alone forms aggregated structures with voids. Obviously, the presence of the buffer layer may serve, among other functions, to block such voids and thus block shunt paths, a function, which is in agreement with the experimental findings on buffer layer reported by other works [20,21]. XRD patterns 
of the perovskite/titania film shown in Figure $\mathbf{3}$ revealed a well-defined crystallinity of the perovskite film with narrow and strong diffraction peaks. The peaks corresponding to the perovskite film appeared at approximately $14.24^{\circ}(110), 20.16^{\circ}(112), 28.59^{\circ}(220), 31.81^{\circ}$ (310), $40.67^{\circ}(224)$, and $43.24^{\circ}$ (330) crystal planes, which correspond to the reflections from the tetragonal phase of the perovskite [37-39]. There are no unidentified peaks besides those attributed to $\mathrm{FTO}, \mathrm{TiO}_{2}$ and perovskite, indicating that a pure phase of perovskite was grown on the mesoporous $\mathrm{TiO}_{2}$ scaffold.

\section{Photon to charge conversion efficiency (PCE) of the PSC devices}

PSC devices of various compositions have been constructed and were characterized by recording their current-voltage data. Figure 4 and Table 1 report the obtained results. Figure 4a reports data on devices made with $\mathrm{CuBuPc}$ as HTM either alone or in the presence of $\mathrm{Al}_{2} \mathrm{O}_{3}$ or $\mathrm{GO}$ buffer layer. Figure $4 \mathbf{b}$ reports corresponding data obtained by using spiroOMeTAD as reference HTM in the place of $\mathrm{CuBuPc}$, for comparison. The beneficial effect produced in the presence of a buffer layer is more than obvious in Figure 4a. This effect is much more pronounced in the case of $\mathrm{CuBuPc}$ than in the case of spiro-OMeTAD. Thus, both $\mathrm{FF}$ and $\mathrm{V}_{\mathrm{OC}}$ largely increased and this resulted in a dramatic increase of the cell efficiency, which changed from $7.3 \%$ to $14.4 \%$. Increase of the fill factor and of the open-circuit voltage are standard indicators of blocking of the shunt paths across the cell $[\mathbf{2 0 , 2 3 , 2 4 ]}$. Indeed, as seen in Figure 2e, CuBuPc films are composed of aggregates, possibly due to its lower solubility in chlorobenzene [40], and this results to the creation of voids that may become paths, for example, of Au penetration. Such paths are obviously blocked by the underlying buffer layer, as indicated by Figure 2f. This idea is supported by the smaller effect produced in the case of spiro-OMeTAD, which is known to form smoother films with less voids. We believe that the reason for this difference is the smoother films made by spiro-OMeTAD with 
higher solubility in chlorobenzene and with less voids, particularly in the presence of Li-TFSI [41].

The current-voltage data of Figure 4 demonstrate the superiority of GO as buffer layer. Most researchers have used metallic oxides as buffer layer $[\mathbf{2 0 , 2 1 , 2 3 , 2 4 ] , ~ h o w e v e r , ~ t h e ~}$ present data highlight the importance and the superiority of GO. The nature of the effects caused by GO should not be different from that of metal oxides but we believe that the particularity of the GO structure may assist better film formation, especially in the case of $\mathrm{CuBuPc}$.

It is interesting to also inspect the data of Figure 5, which shows the corresponding IPCE spectra for all the above device variants. In all cases, the prevalent functional species for light absorption and charge generation is perovskite. Therefore, the shape of the spectra is similar in all six cases. The maximum IPCE value is in line with the maximum current density produced in each case ( $c f$. Figures $\mathbf{4}$ and $\mathbf{5}$ ).

The results of Figures $\mathbf{4}$ and $\mathbf{5}$ present for the first time an important finding: n-butylsubstituted copper phthalocyanine $(\mathrm{CuBuPc})$ can compete spiro-OMeTAD as HTM for perovskite solar cells. CuBuPc alone gave so far a modest efficiency [18] but apparently the introduction of GO as buffer layer was the crucial factor that repaired its deficiencies. We believe that the most serious of these deficiencies was the extended aggregation and the existence of voids in their films. The presence of GO apparently limits this disadvantage. At this point, it must be pointed out that the device was inactive in the presence of GO but in the absence of $\mathrm{CuBuPc}$. This means that GO does function as buffer layer but not as HTM, at least under the present configuration. 


\section{Electrochemical Impedance Spectroscopy analysis}

In order to get further insight on the impact of the GO buffer layer on hole transport characteristic of PSCs, EIS measurements have been additionally performed. Figure 6 shows Nyquist and Bode-phase plots of the above PSC devices. The spectra are characterized by two major arcs at low-intermediate and high frequencies. The high-frequency part of the spectra contains information on the transport resistance and series resistance elements, as well as dielectric contributions [42]. The low frequency arc is attributed to recombination in the photoactive layer [43]. It is evident from Figure 6 that the main characteristic frequency peak of the Bode plots of PSC devices containing $\mathrm{CuBuPc/GO}$ layer shifted towards lower frequencies and the corresponding central arc in the Nyquist plots became wider with respect to those containing neat $\mathrm{CuBuPc}$ layer, in particular for the measurements under illumination conditions. This means that the GO buffer layer not only can help to form a blocking layer, but also may retard the charge recombination, especially under illumination. In other words, charge recombination will be impeded when the photogenerated holes could be transported more efficiently from active perovskite layer via $\mathrm{CuBuPc/GO}$ layer.

\section{Photoluminescence data}

The benefits produced by the presence of the buffer layer are further highlighted by photoluminescence data, as seen in Figure 7. A perovskite film has been deposited on plain glass (without FTO or $\mathrm{TiO}_{2}$ layer) and its absorption and photoluminescence spectra have been recorded. Interestingly, organometal halide perovskites emit substantial photoluminescence, which depends on halide composition [44]. Then on the top of the perovskite film a layer of $\mathrm{CuBuPc}$ was deposited with or without an intermediate $\mathrm{Al}_{2} \mathrm{O}_{3}$ or GO buffer layer. In the presence of $\mathrm{CuBuPc}$, the luminescence was extensively quenched, suggesting efficient hole scavenging by CuBuPc. It is interesting to note that quenching was 
even more extensive in the presence of a buffer layer, GO being again the most effective. The results of Figure 7 highlight $\mathrm{CuBuPc}$ as efficient hole scavenger but they also highlight GO as a means to further facilitate this functionality. Thus, we can conclude that buffer layers, in particularly, GO layer, can efficiently suppress charge recombination in the PSCs, a conclusion which is in line with previous reports [20-22]. The functionality of GO in PSCs comprising $\mathrm{CuBuPc}$ as HTM is pictorially summarized by the energy diagram of Figure 8.

\section{Conclusions}

Soluble copper phthalocyanine can be used as HTM in organometal halide perovskite solar cells with equivalent performance as the standard spiro-OMeTAD. Therefore, $\mathrm{CuBuPc}$, which is a stable and rather simple molecule with lower commercial price than spiroOMeTAD, can be a valuable substituent of the latter. High performance of $\mathrm{CuBuPc}$ was achieved in the presence of a buffer layer, especially graphene oxide, which seems to be particularly fit to the case of CuBuPc.

\section{Acknowledgements}

M.R. Mohammadi and E. Nouri wish to thank the financial support by Sharif University of Technology through research grant no. G940309, and especially the financial support by Iran National Science Foundation (INSF). Dr. Zong-Xiang Xu would like to thank the financial support from National Natural Science Foundation of China (Nos. 210381), and Special Funds for the Development of Strategic Emerging Industries in Shenzhen (JCYJ20150630145302239). 


\section{References}

[1] B. O'Regan, M. Grätzel, A Low-Cost, High-Efficiency Solar Cell Based on DyeSensitized Colloidal $\mathrm{TiO}_{2}$ Films, Nature, 353 (1991) 737-740.

[2] A. Kojima, K. Teshima, Y. Shirai, T. Miyasaka, Organometal Halide Perovskites as Visible-Light Sensitizers for Photovoltaic Cells, J. Am. Chem. Soc. 131 (2009) 60506051.

[3] S.D. Stranks, G.E. Eperon, G. Grancini, C. Menelaou, M.J.P. Alcocer, T. Leijtens, L.M. Herz, A. Petrozza, H.J. Snaith, Electron-Hole Diffusion Lengths Exceeding 1 Micrometer in an Organometal Trihalide Perovskite Absorber, Science, 342 (2013) $341-344$.

[4] Q. Dong1, Y. Fang1, Y. Shao1, P. Mulligan, J. Qiu, L. Cao, J. Huang, Electron-Hole Diffusion Lengths $>175 \mu \mathrm{m}$ in Solution-Grown $\mathrm{CH}_{3} \mathrm{NH}_{3} \mathrm{PbI}_{3}$ Single Crystals, Science, 347(2015) 967-970.

[5] D.W. de Quilettes, S.M. Vorpahl, S.D. Stranks, H. Nagaoka, G.E. Eperon, M.E. Ziffer, H.J. Snaith, D.S. Ginger, Impact of Microstructure on Local Carrier Lifetime in Perovskite Solar Cells, Science 348 (2015) 683-686.

[6] S.D. Stranks, H.J. Snaith, Metal-Halide Perovskites for Photovoltaic and Light-mitting Devices, Nat. Nanotechnol, 10 (2015) 391-402.

[7] F.Bella, Polymer electrolytes and perovskites: lights and shadows in photovoltaic devices, Electrochimica Acta 175 (2015) 151-161

[8] J. H. Noh, N.J. Jeon, Y.C. Choi, M.K. Nazeeruddin, M. Grätzel, S.I. Seok, Nanostructured $\mathrm{TiO}_{2} / \mathrm{CH}_{3} \mathrm{NH}_{3} \mathrm{PbI}_{3}$ Heterojunction Solar Cells Employing SpiroOMeTAD/Co-Complex as Hole-Transporting Material, J. Mater. Chem. A, 1 (2013) 11842-11847. 
[9] T. Malinauskas, D.T. Luksiene, R. Sens, M. Daskeviciene, R. Send, H. Wonneberger, V. Jankauskas, I. Bruder, V. Getautis, Enhancing Thermal Stability and Lifetime of Solid-State Dye-Sensitized Solar Cells via Molecular Engineering of the HoleTransporting Material Spiro-OMeTAD, ACS Appl. Mater. Interfaces, 7 (2015) 1110711116.

[10] M. Saliba, S. Orlandi, T. Matsui, S. Aghazada, M. Cavazzini, J.-P. Correa-Baena, P. Gao, R. Scopelliti, E. Mosconi, K.-H. Dahmen, F. De Angelis, A. Abate, A. Hagfeldt, G. Pozzi, M. Graetzel, M. K. Nazeeruddin, A molecularly engineered hole-transporting material for efficient perovskite solar cells, Nat. Energy, 1 (2016) 15017.

[11] H. Li, K. Fu, A. Hagfeldt, M. Grätzel, S.G. Mhaisalkar, A.C. Grimsdale, A Simple 3,4Ethylenedioxythiophene Based Hole-Transporting Material for Perovskite Solar Cells, Angew. Chem., Int. Ed. 2014 , 53 , 4085-4088.

[12] N.J. Jeon, J. Lee, J.H. Noh, M.K. Nazeeruddin, M. Grätzel, S.I. Seok, Efficient Inorganic-Organic Hybrid Perovskite Solar Cells Based on Pyrene Arylamine Derivatives as Hole-Transporting Materials, J. Am. Chem. Soc., 135 (2013) 1908719090.

[13] P. Qin, S. Paek, M.I. Dar, N. Pellet, J. Ko, M. Grätzel, M.K. Nazeeruddin, Perovskite Solar Cells with $12.8 \%$ Efficiency by Using Conjugated Quinolizino Acridine Based Hole Transporting Material, J. Am. Chem. Soc., 136 (2014) 8516-8519.

[14] I. L. Duarte, M. Wang, R. H. Baker, M. Ince, M.V. Martínez-Díaz, M.K. Nazeeruddin, T. Torres, M. Grätzel, Molecular Engineering of Zinc Phthalocyanines with Phosphinic Acid Anchoring Groups, Angew. Chemie, 124 (2012) 1931-1934.

[15] C. V. Kumar, G. Sfyri, D. Raptis, E. Stathatos, P. Lianos, Perovskite Solar Cell with Low Cost Cu-Phthalocyanine as Hole Transporting Material, RSC Adv., 5 (2015) $3786-3791$. 
[16] G. Sfyri, C. V. Kumar, G. Sabapathi, L. Giribabu, K. S. Andrikopoulos, E. Stathatos, P. Lianos, Subphthalocyanine as Hole Transporting Material for Perovskite Solar Cells, RSC Adv. 5 (2015) 69813-69818.

[17] G. Sfyri, C. V. Kumar, Y. L. Wang, Z. X. Xu, C. A. Krontiras, P. Lianos, Tetra methyl substituted $\mathrm{Cu}(\mathrm{II})$ phthalocyanine as alternative hole transporting material for organometal halide perovskite solar cells, Appl. Surf. Sci. 360 (2016) 767-771.

[18] G.Sfyri, Q.Chen, Y.-W.Lin, Y.-L.Wang, E.Nouri, Z.-X.Xu, P.Lianos, Soluble butyl substituted copper phthalocyanine as alternative hole-transporting material for solution processed perovskite solar cells, Electrochimica Acta, 212 (2016) 929-933.

[19] E. Nouri, J.V.S. Krishna, C.V. Kumar, V. Dracopoulos, L. Giribabu, M.R. Mohammadi, P. Lianos, Soluble Tetratriphenylamine Zn Phthalocyanine as Hole Transporting Material for Perovskite Solar Cells, Electrochim. Acta, 222 (2016) 875-880.

[20] S. Guarnera, A. Abate, W. Zhang, J.M. Foster, G. Richardson, A. Petrozza, H.J. Snaith, Improving the Long-Term Stability of Perovskite Solar Cells with a Porous $\mathrm{Al}_{2} \mathrm{O}_{3}$ Buffer-Layer, J Phys Chem Lett. 6 (2015) 432-437.

[21] S.K. Pathak, A. Abate, T. Leijtens, D.J. Hollman, J. Teuscher, L. Pazos, P. Docampo, U. Steiner, H.J. Snaith, Towards Long-Term Photostability of Solid-State Dye Sensitized Solar Cells, Adv. Energy Mater., 4 (2014) 1301667(1-9).

[22] W. Li, H. Dong, L. Wang, N. Li, X. Guo, J. Li, Y. Qiu, Montmorillonite as Bifunctional Buffer Layer Material for Hybrid Perovskite Solar Cells with Protection from Corrosion and Retarding Recombination, J. Mater. Chem. A, 2 (2014) 13587-13592.

[23] C.Y. Chang, W.K. Huang, J.L. Wu, Y.C. Chang, K.T. Lee, C.T. Chen, Roomtemperature Solution-Processed n-Doped Zirconium Oxide Cathode Buffer Layer for Efficient and Stable Organic and Hybrid Perovskite Solar Cells, Chem. Mater., 28 (2016) 242-251. 
[24] X. Jia, L. Zhang, Q. Luo, H. Lu, X. Li, Z. Xie, Y. Yang, Y. Q. Li, X. Liu, C.Q. Ma, Power Conversion Efficiency and Device Stability Improvement of Inverted Perovskite Solar Cells by Using a ZnO:PFN Composite Cathode Buffer Layer, ACS Appl. Mater. Interfaces, DOI: 10.1021/acsami.6b03724.

[25] J.F. Li, C. Zhao, H. Zhang, J.F. Tong, P. Zhang, C.Y. Yang, Y.J. Xia, D.W. Fan, Improving the performance of perovskite solar cells with glycerol-doped PEDOT:PSS buffer layer, Chin. Phys. B, 25 (2016) 028402 (1-5).

[26] X. Liu, H. Yu, L. Yan, Q. Dong, Q. Wan, Y. Zhou, B. Song, Y. Li, Triple Cathode Buffer Layers Composed of PCBM, C60 and LiF for High Performance Planar Perovskite Solar Cells, ACS Appl. Mater. Interfaces, 7 (2015) 6230-6237.

[27] C.Y. Chang, W.K. Huang, J.L. Wu, Y.C. Chang, K.T. Lee, C.T. Chen, RoomTemperature Solution-Processed n-Doped Zirconium Oxide Cathode Buffer Layer for Efficient and Stable Organic and Hybrid Perovskite Solar Cells, Chem. Mater., 28 (2016) 242-251.

[28] F.J. Ramos, M. Ince, M. Urbani, A. Abate, M. Grätzel, S. Ahmad, T. Torres, M.K. Nazeeruddin, Non-aggregated Zn(II)octa(2,6-Diphenylphenoxy) Phthalocyanine as a Hole Transporting Material for Efficient Perovskite Solar Cells, Dalt. Trans. 44 (2015) 10847-10851.

[29] A.Agresti, S.Pescetelli, B.Taheri, A.E.Del Rio Castillo, L.Cina, F.Bonaccorso, A.Di Carlo, Graphene-Perovskite Solar Cells Exceed 18\% Efficiency: A Stability Study, ChemSusChem 9 (2016) $1-12$.

[30] A. Agresti , S.Pescetelli , L.Cinà , D. Konios , G.Kakavelakis, E. Kymakis , A. Di Carlo, Efficiency and Stability Enhancement in Perovskite Solar Cells by Inserting Lithium-Neutralized Graphene Oxide as Electron Transporting Layer, Adv. Funct. Mater. 26 (2016) 2686-2694. 
[31] W.Li, H.Dong, X.Guo, N.Li, J.Li, G.Niu, L.Wang, Graphene oxide as dual functional interface modifier for improving wettability and retarding recombination in hybrid perovskite solar cells, J. Mater. Chem. A 2 (2014) 20105-20111.

[32] T.Gatti, S.Casaluci, M.Prato, M.Salerno, F.Di Stasio, A.Ansaldo, E.Menna , A.Di Carlo, F. Bonaccorso, Boosting Perovskite Solar Cells Performance and Stability through Doping a Poly-3(hexylthiophene) Hole Transporting Material with Organic Functionalized Carbon Nanostructures, Adv. Funct. Mater. 26 (2016) 7443-7453.

[33] F.Bella, G.Griffini, J.P.Correa-Baena, G.Saracco, M.Grätzel, A.Hagfeldt, S.Turri, C.Gerbaldi, Improving efficiency and stability of perovskite solar cells with photocurable fluoropolymers, Science 354 (2016) 203-206.

[34] Z.Song, A.Abate , S.C. Watthage, G.K.Liyanage, A.B.Phillips, U.Steiner, M.Graetzel, M.J.Heben, Perovskite Solar Cell Stability in Humid Air: Partially Reversible Phase Transitions in the $\mathrm{PbI}_{2}-\mathrm{CH}_{3} \mathrm{NH}_{3} \mathrm{I}-\mathrm{H}_{2} \mathrm{O}$ System, Adv. Energy Mater. 6 (2016) 1600846.

[35] A.K.Baranwal, S.Kanaya, T.A.Nirmal Peiris, G.Mizuta, T.Nishina, H.Kanda, T.Miyasaka, H.Segawa, S.Ito, $100^{\circ} \mathrm{C}$ Thermal Stability of Printable Perovskite Solar Cells Using Porous Carbon Counter Electrodes, ChemSusChem 9 (2016) 2604 - 2608.

[36] W. Hummers, R. Offeman, Preparation of Graphitic Oxide. J Am Chem Soc 80 (1958) 1339-1339.

[37] J. Qiu, Y. Qiu, K. Yan, M. Zhong, C. Mu, H. Yan, S. Yang, All-Solid-State Hybrid Solar Cells Based on a New Organometal Halide Perovskite Sensitizer and OneDimensional $\mathrm{TiO}_{2}$ Nanowire Arrays, Nanoscale, 5 (2013) 3245-3248.

[38] T. Baikie, Y. Fang, J.M. Kadro, M. Schreyer, F. Wei, S.G. Mhaisalkar, M. Gratzel, T.J. White, Synthesis and Crystal Chemistry of the Hybrid Perovskite $\left(\mathrm{CH}_{3} \mathrm{NH}_{3}\right) \mathrm{PbI}_{3}$ for Solid-State Sensitised Solar Cell Applications. J. Mater. Chem. A, 1 (2013) 5628-5641. 
[39] L.A. Kosyachenko, Solar Cells - New Approaches and Reviews, Chapter 3, InTech, 2015.

[40] F. Ghani, J. Kristen, H. Riegler, Solubility Properties of Unsubstituted Metal Phthalocyanines in Different Types of Solvents, J. Chem. Eng. Data, 57 (2012) 439449.

[41] W.H.Nguyen, C.D.Bailie, E.L.Unger, M.D.McGehee, Enhancing the Hole-Conductivity of Spiro-OMeTAD without Oxygen or Lithium Salts by Using Spiro (TFSI) $)_{2}$ in Perovskite and Dye-Sensitized Solar Cells, J. Am. Chem. Soc., 136 (2014) $10996-11001$.

[42] G.G. Belmonte, A. Munar, E.M. Barea, J. Bisquert, I. Ugarte, R. Pacios, Charge Carrier Mobility and Lifetime of Organic Bulk Heterojunctions Analyzed by Impedance Spectroscopy, Org. Electron., 9 (2008) 847-851.

[43] J. Bisquert, F.F. Santiago, I.M. Sero, G.G. Belmonte, S. Gimenez, Electron Lifetime in Dye-Sensitized Solar Cells: Theory and Interpretation of Measurements, J. Phys. Chem. C, 113 (2009) 17278-17290.

[44] B.R. Sutherland, E.H. Sargent, Perovskite photonic sources, Nature Photonics 10 (2016) 295-302. 
Table 1. Current -voltage data extracted from Figure 4.

\begin{tabular}{lcccc}
\hline Hole-Transporting Layer & $\mathbf{J}_{\mathbf{S C}}\left(\mathbf{m A} / \mathbf{c m}^{\mathbf{2}}\right)$ & $\mathbf{V}_{\mathbf{O C}}(\mathbf{V})$ & $\mathbf{F F}$ & $\mathbf{\eta} \%$ \\
\hline CuBuPc (neat) & 17.0 & 0.89 & 0.48 & 7.3 \\
CuBuPc (Al $\left.\mathbf{O}_{3}\right)$ & 19.5 & 0.99 & 0.50 & 9.7 \\
CuBuPc (GO) & 20.9 & 1.04 & 0.66 & 14.4 \\
Spiro (neat) & 16.8 & 0.84 & 0.61 & 8.6 \\
Spiro (Al $\left.\mathbf{O}_{3}\right)$ & 19.4 & 0.85 & 0.55 & 9.1 \\
Spiro (GO) & 21.7 & 0.87 & 0.66 & 12.5 \\
\hline
\end{tabular}




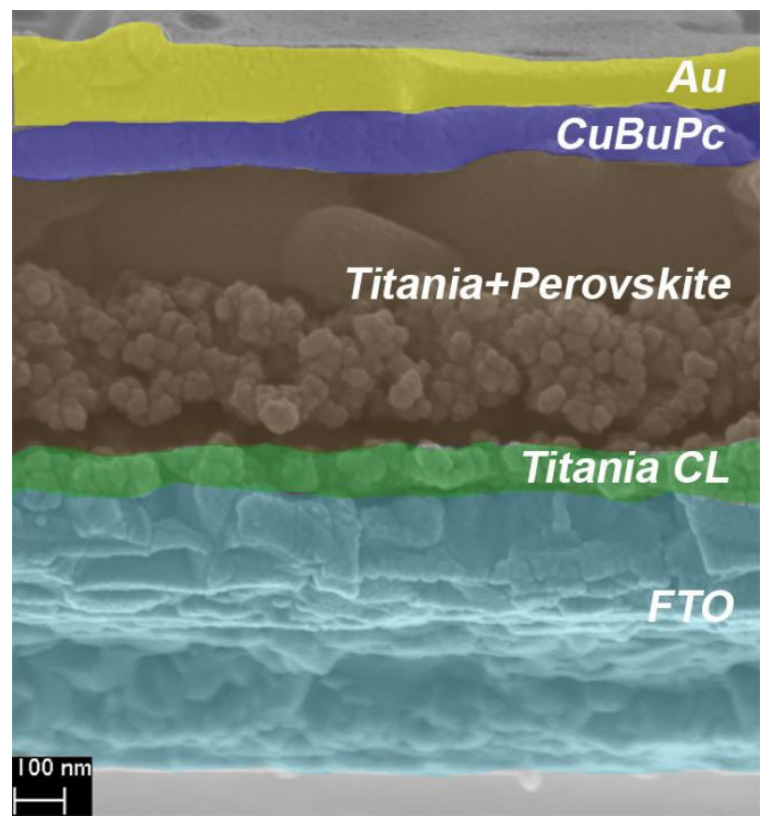

Figure 1. Cross-sectional FESEM image of the subsequent layers of a PSC device 

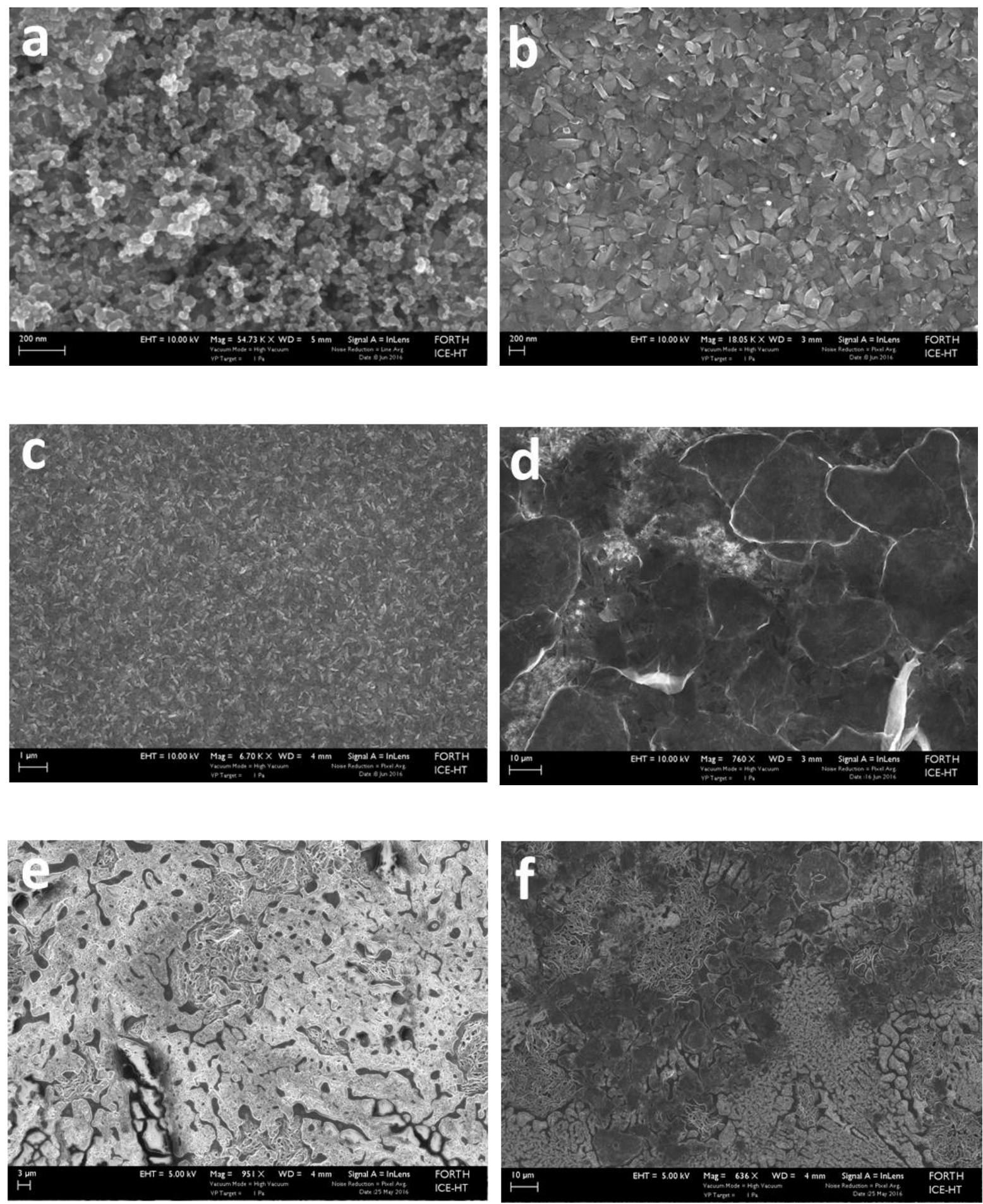

Figure 2. FESEM top views of the subsequent layers making the PSC device: (a) titania; ( $b$ and c) perovskite; (d) GO on the top of the perovskite film; (e) CuBuPc on the top of perovskite without buffer layer; and (f) CuBuPc with underlying GO buffer layer. The scale bar is $200 \mathrm{~nm}$ in (a) and (b), $1 \mu \mathrm{m}$ in (c), $3 \mu \mathrm{m}$ in (e) and $10 \mu \mathrm{m}$ in (d) and (f). 


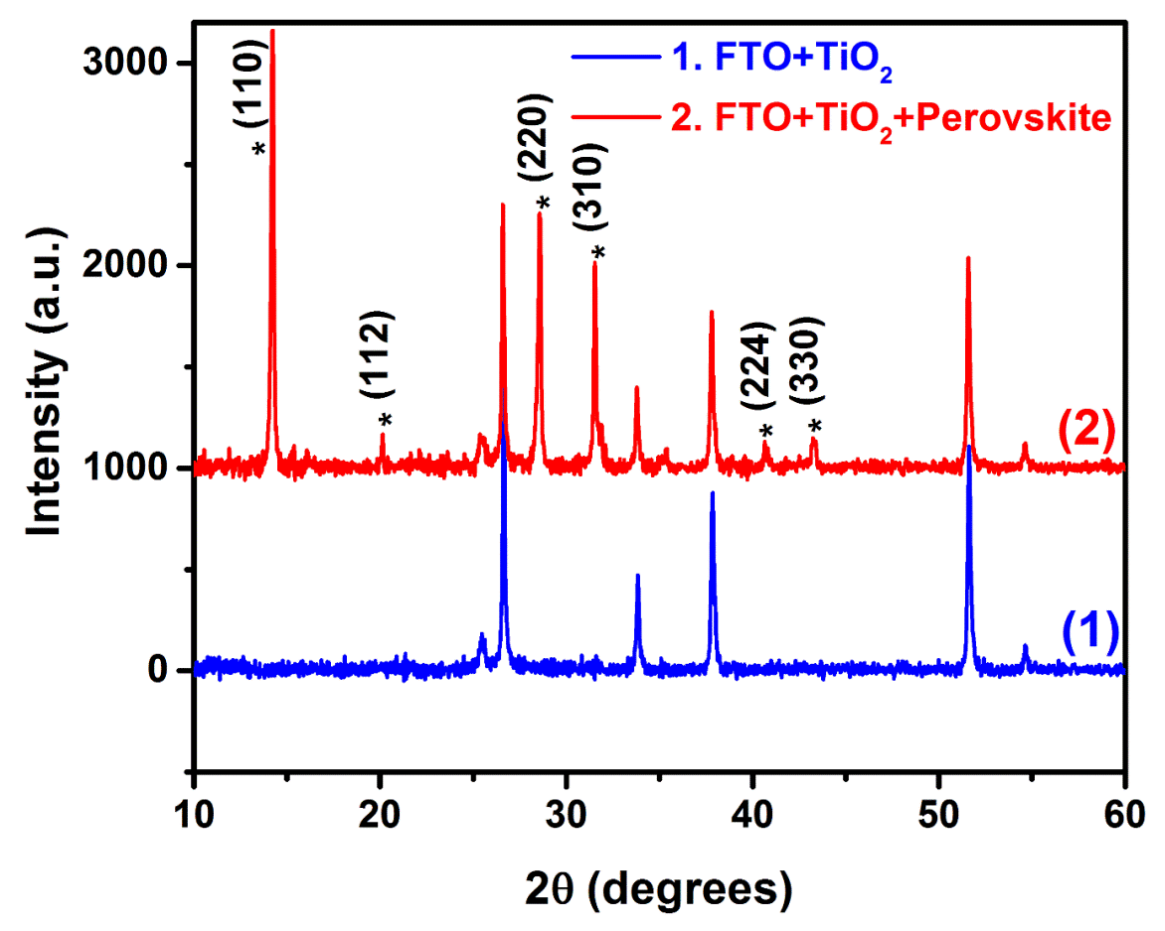

Figure 3. XRD patterns of mesoporous $\mathrm{TiO}_{2}$ film on FTO glass: (1) without and (2) with deposition of perovskite film on $\mathrm{TiO}_{2}$ surface. Characteristic peaks associated with the perovskite structure are labeled and denoted with asterisks. 

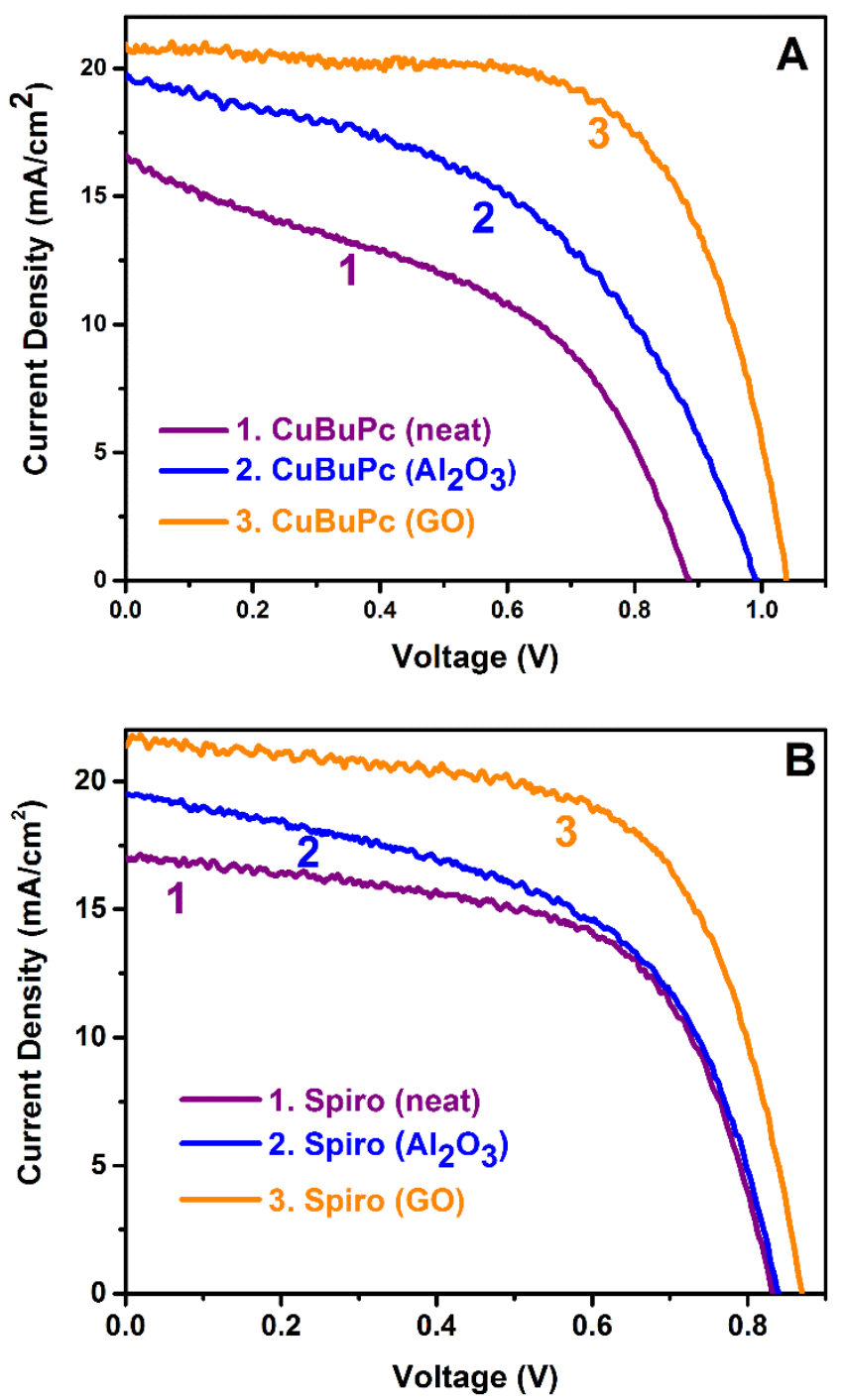

Figure 4. Current-voltage data for PSC devices made by employing CuBuPc (A) or spiroOMeTAD (B) as HTM in the absence or in the presence of $\mathrm{Al}_{2} \mathrm{O}_{3}$ or $\mathrm{GO}$ buffer layer. Curves showing hysteresis by reverse plotting were not included to avoid confusion but they are included in the supporting information file. 

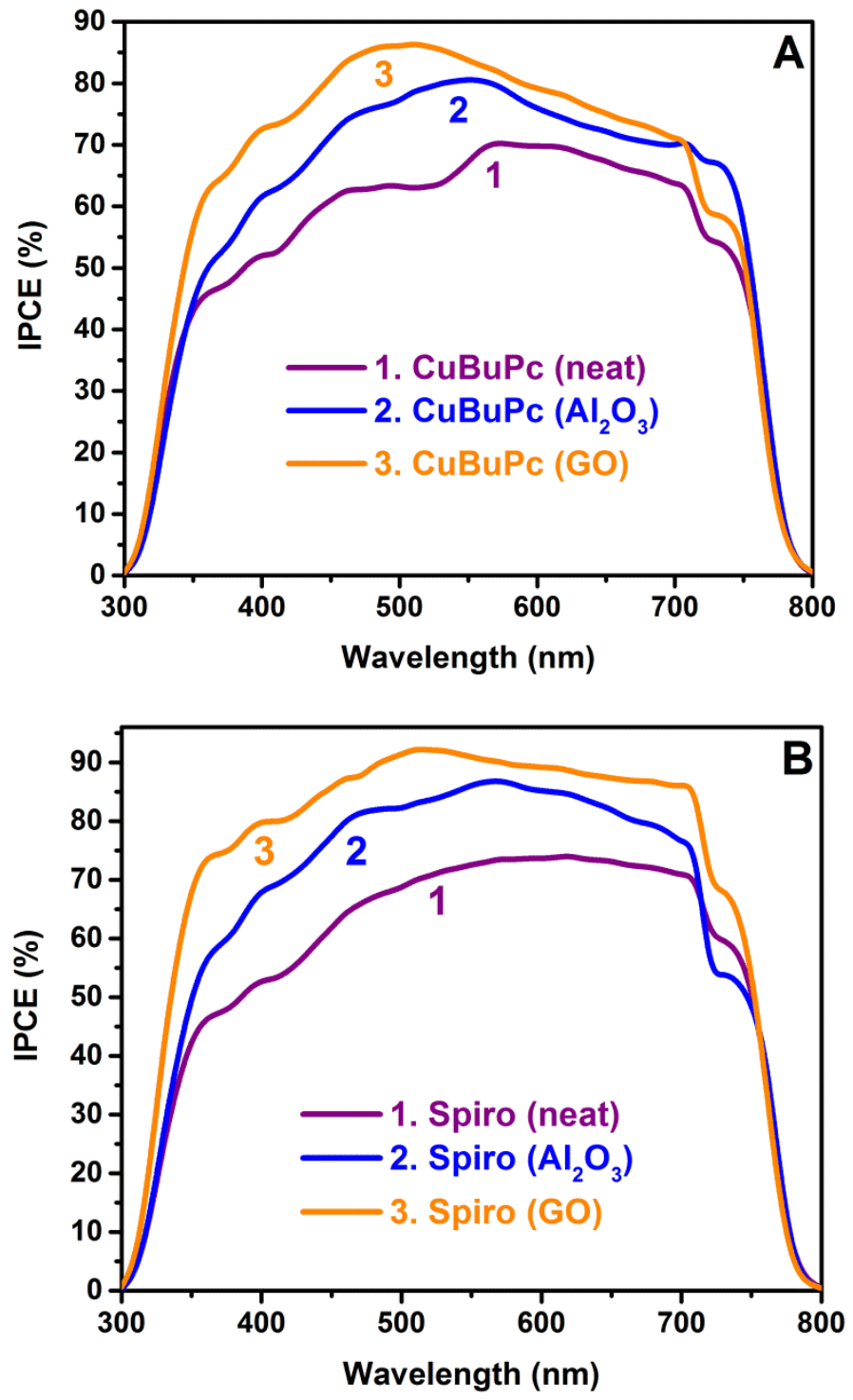

Figure 5. IPCE\% spectra for PSC devices made by employing CuBuPc (A) or spiroOMeTAD (B) as HTM in the absence or in the presence of $\mathrm{Al}_{2} \mathrm{O}_{3}$ or $\mathrm{GO}$ buffer layer. 

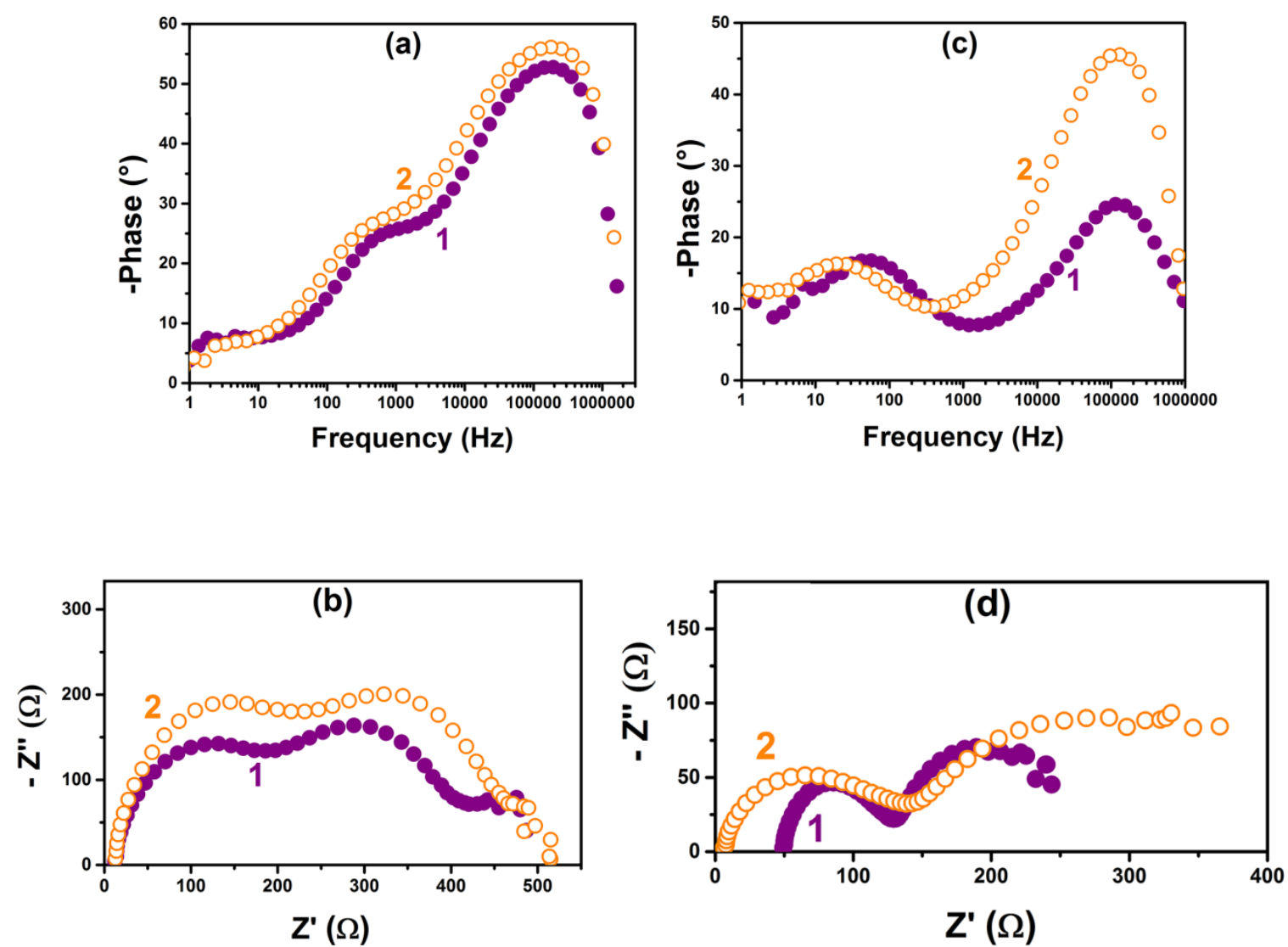

Figure 6. Bode-phase plots $(a, c)$ and Nyquist plots $(b, d)$ at $V_{a p p}=V_{O C}$ under $(a, b)$ dark and (c,d) illumination conditions for PSCs employing CuBuPc as HTM: (1) in the absence and (2) in the presence of GO buffer layer. 


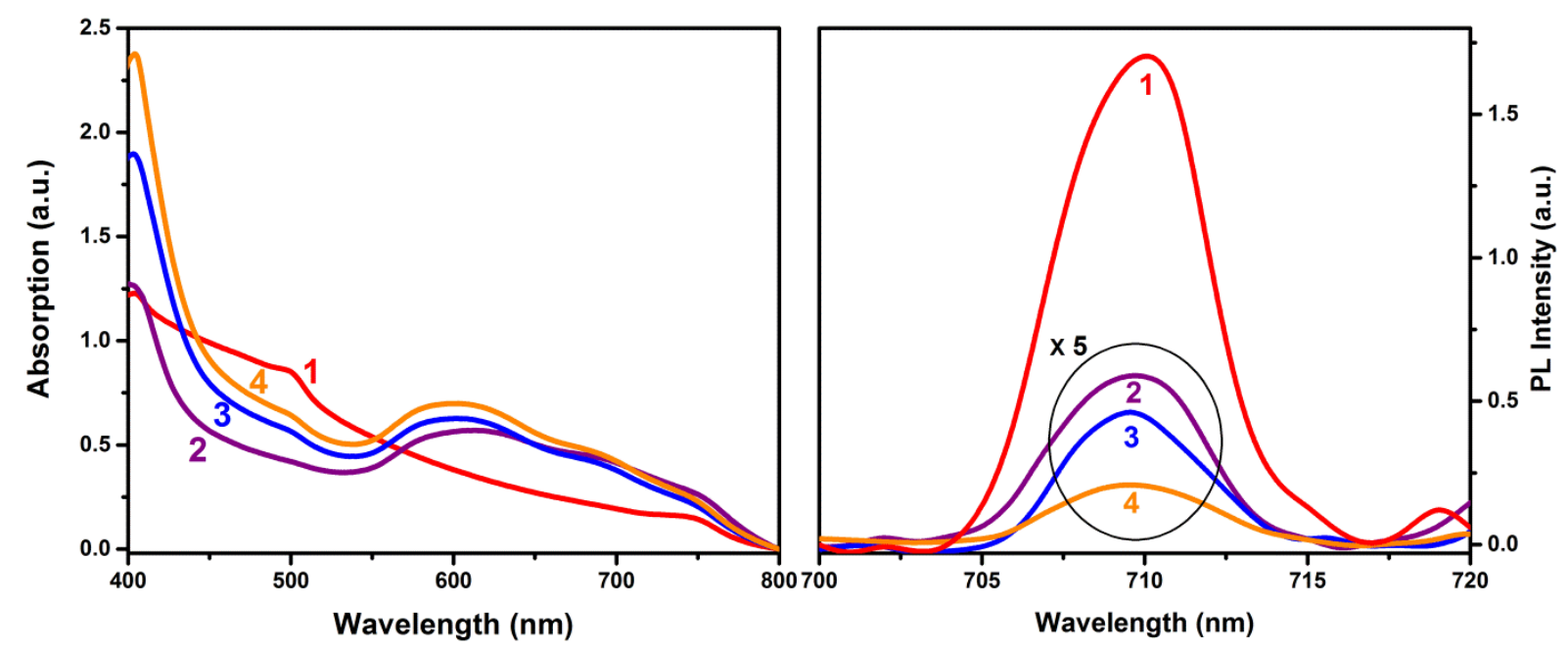

Figure 7. Absorption (left) and luminescence (right) spectra of perovskite films deposited on plain glass without FTO or a titania film, with or without an intermediate buffer layer and a CuBuPc layer on the top,: (1) perovskite film alone; (2) CuBuPc /perovskite; (3)CuBuPc $/ \mathrm{Al}_{2} \mathrm{O}_{3} /$ perovskite; and (4)CuBuPc /GO/perovskite. Photoluminescence was recorded by excitation at $450 \mathrm{~nm}$. 


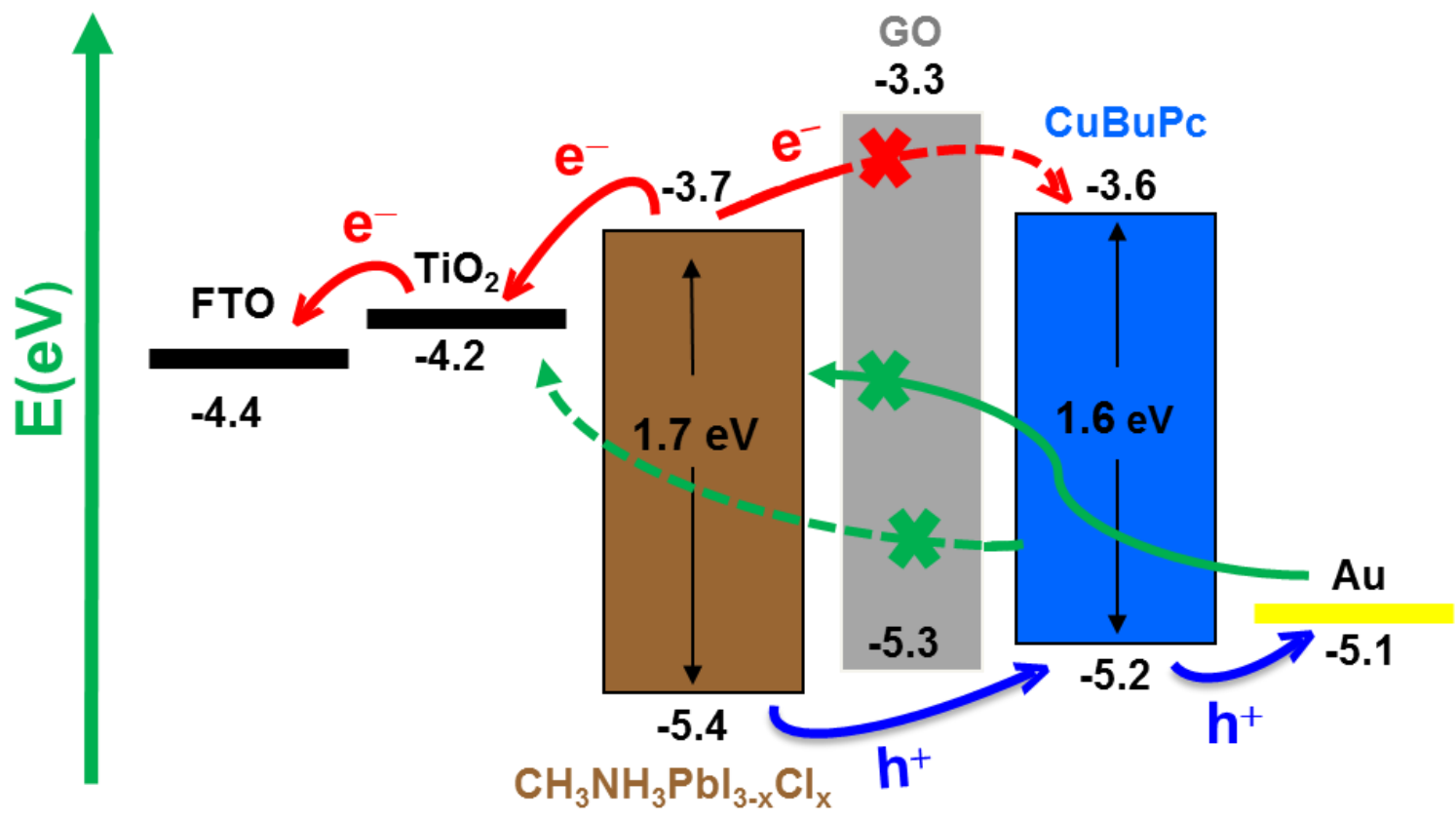

Figure 8. Placement of energy states and suggested charge transfer in PSCs based on CUBuPc as HTM. The diagram highlights the elimination of shunt paths across the cell. 


\section{Graphical Abstract}

for the manuscript "Introduction of Graphene Oxide as Buffer Layer in Perovskite Solar Cells and the Promotion of soluble n-butyl-substituted Copper Phthalocyanine as Efficient Hole Transporting Material" by Nouri et al.

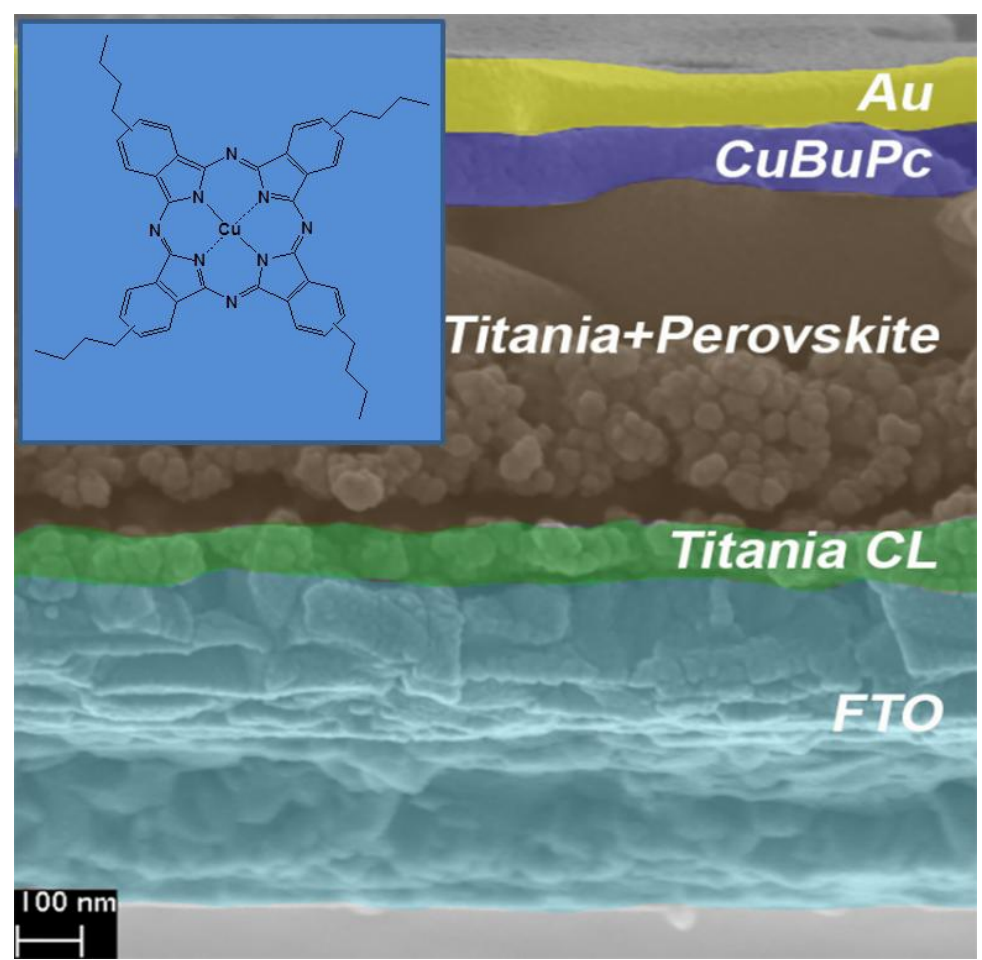

